\title{
Revolutionary Violence
}




\title{
Never the Same Again On Some Recent Interpretations of the French Revolution
}

\author{
Francesco Benigno
}

Once upon a time there was the Revolution, without an adjective, written "with a capital R to denote the French Revolution of 1789." Its history was much more than the narrative of a pivotal event that consecrated the republican identity of the French nation: it described the birth of the modern world and offered an interpretation of this new environment, inventing words and ideas to describe it that shaped the very conception of revolutionary change as a laboratory of social transformation. This event thus became the norm and matrix for all subsequent revolutions and, concurrently, the explanation for all those that had previously occurred-an essential marker on the road to progress and a model for all attempts at social change. Over the last twenty years, however, the Revolution has lost this centrality to discourse, and the violent political debate and ideological controversy that animated intellectual discussion during the bicentenary of 1989 have subsided. ${ }^{2}$ Today we may ask ourselves the following: Now that the object has "cooled down," what new questions may be asked about the French Revolution? What motives can be found for exploring anew such a well-known and closely studied subject? Or, to cut to the heart of the matter, if the "Great Revolution" is no longer what it once was, what does it represent today?

\footnotetext{
This article was translated from the French by Rodney Coward and edited by Chloe Morgan and Stephen Sawyer.

1. Henri Lévy-Bruhl, "Révolution," Bulletin du Centre international de synthèse. Section de synthèse historique 6 (1928): 34-39, here p. 34.

2. Francesco Benigno, Mirrors of Revolution: Conflict and Political Identity in Early Modern

Europe [1999] (Turnhout: Brepols, 2010).
} 
Three recent books raise-more or less explicitly-these questions and for this reason deserve consideration. ${ }^{3}$ These are works by non-French historiansone is American, another British, and the third Italian - who differ as much in their training as in their approaches. They underscore the persistence of interest outside France for an event that has never ceased to be considered essential and even definitive. They also testify to an interest in returning to general interpretations and rediscovering, if not a single explanation for the Revolution, at least the fundamental mechanisms behind it, after a period during which the quest for its ultimate causes had been abandoned. ${ }^{4}$ Though they each pursue particular avenues of current historical research (the history of emotions, intellectual history, an approach rooted in experimental anthropology), these works share a common feature: their reluctance to examine the "political structure" of the revolutionary period, an unwillingness which may seem either justifiable or incomprehensible, depending on the case in question. At the end of this critical review, I will return to the need to further examine, alongside other interesting lines of research, the concrete political context that structured revolutionary politics, a veritable "battlefield" that involved not only the equilibrium between courtiers, ministers, and parliamentarians, but also the dialectic generated by the constant opposition of dozens of newspapers and pamphlets, the close interplay of the sections between themselves and with the Paris Commune, the role of the National Guard and the armed crowd, and the ever-growing presence of the army.

\section{The Interplay and Implications of Emotions}

With his book The Coming of the Terror in the French Revolution, Timothy Tackett further develops the work that has made him one of the most important historians of the French Revolution. This extension, which takes place on several levels, is thematic rather than chronological. At the core of his previous book, Becoming $a$ Revolutionary, ${ }^{5}$ lay the crucial intuition (to which many would probably subscribe) that the Revolution offered a retrospective vision of its own history-a vision from which the author nevertheless managed to emancipate himself by rediscovering, in the very unfolding of the revolutionary process, the causes of an outcome which was not initially foreseen. Through a series of decisive events, in most

3. Timothy Tackett, The Coming of the Terror in the French Revolution (Cambridge: Belknap Press of Harvard University Press, 2015); Jonathan Israel, Revolutionary Ideas: An Intellectual History of the French Revolution from the Rights of Man to Robespierre (Princeton: Princeton University Press, 2014); Haim Burstin, Révolutionnaires. Pour une anthropologie politique de la Révolution française (Paris: Vendémiaire, 2013).

4. On causality, see Emmanuel Akyeampong et al., "AHR Conversation: Explaining Historical Change; or, The Lost History of Causes," American Historical Review 120, no. 4 (2015): 1369-423.

5. Timothy Tackett, Becoming a Revolutionary: The Deputies of the French National Assembly and the Emergence of a Revolutionary Culture, 1789-1790 (Princeton: Princeton University Press, 1996). 
cases unpredictable and therefore completely unanticipated, the Revolution transformed things and above all people-for, as Lazare Carnot once put it, "a man does not begin as a revolutionary; he becomes one" gradually through experience and learning. ${ }^{6}$ In sum, it was not the revolutionary that made the revolution, but the revolution-understood as an intense sequence of sensational and closely interlinked events- that made the revolutionary.

Applying a similar principle, The Coming of the Terror addresses another problem: the perplexing question of the origins of the Terror. So doing, it poses the question of the coexistence of good and evil at the very heart of the Revolution: the Declaration of the Rights of Man and the Citizen alongside the massacres of September 1792, the fundamental civil and social advances in parallel with the arbitrary, brutal repression orchestrated by the state-what Dominique Joseph Garat called "the incredible contrast between our principles and our follies." Tackett wonders how well-meaning people, gentle and high-minded men, could be transformed into bloody assassins, how "both the lamb and the tiger [could] inhabit the same individuals." ${ }^{8}$ In his search for an explanation for what he refers to as a "terrorist mindset," the American historian voices a certain dissatisfaction with the current state of research, which in his opinion suffers from the constraints of an overly narrow interpretative framework. ${ }^{9}$ On the one side, there stands a progressive historiography which has always aimed to resituate the Terror in the troubled historical context that produced it, giving due consideration to the circumstances of the times: the need to face a military challenge at the European level, recurring economic difficulties, a tragic civil war, and insidious counterrevolutionary maneuverings. In other words, the Terror is seen as a temporary, exceptional attempt to deal with a complex set of emergencies. On the other side stands a revisionist historiography, largely influenced by François Furet, which seeks to explain the drift toward the Terror by favoring a principally ideological perspective, attributing to revolutionary radicalism (itself fed by Rousseauist integrism) the refusal of the patriots to accept a diversity of opinion and their tendency to demonize their opponents by transforming them into enemies. ${ }^{10}$

Seeking an alternative explanation of the origins of the Terror, Tackett turns to the "history of emotions," an ill-defined historiographical current which, perhaps precisely because of its indeterminate nature, has met with remarkable success over the last decade. ${ }^{11}$ Recourse to psychology is, in fact, nothing new in studies

6. Quoted in Tackett, The Coming of the Terror, 4.

7. Quoted in ibid., 2.

8. Ibid., 12.

9. Ibid., 342. For a recent contribution offering an overview of these interpretations, see Michel Biard, ed., Les politiques de la Terreur, 1793-1794 (Rennes/Paris: Presses universitaires de Rennes/Société des études robespierristes, 2008).

10. Tackett, The Coming of the Terror, 3-4.

11. Ute Frevert, Emotions in History: Lost and Found (Budapest: Central European University Press, 2015); Rob Boddice, ed., Pain and Emotion in Modern History (Basingstoke: Palgrave Macmillan, 2014); Jonas Liliequist, ed., A History of Emotions, 1200-1800 (London: Pickering and Chatto, 2012); Christophe Prochasson, L'empire des émotions. Les historiens dans la mêlée (Paris: Demopolis, 2008). 
of the Revolution. Tackett is well aware of how insistently traditional historiography has emphasized the emotional nature of the "mob" and the attachment of the armed crowd to the idea of social justice conveyed by stereotypical slogans and images, or spread by rumor. Georges Lefebvre's studies of the Great Fear ${ }^{12}$ and George Rudé's research on the crowd ${ }^{13}$ are well-known examples of this current. The somewhat earlier work of Gustave Le Bon ${ }^{14}$ and Gabriel Tarde ${ }^{15}$ published at the end of the nineteenth century, should also be mentioned, together with the Europe-wide debate to which these authors contributed (as did Scipio Sighele and Georg Simmel). Tackett's omission of this debate is regrettable, as these discussions centered on the hypothesis that individual subjects could undergo a change in consciousness once they were caught up in a group dynamic and hence act in an instinctive, emotional way, or at least in one at variance with ordinary rationally guided principles. This current of thought remained present in a slightly different form throughout the twentieth century, in the wake of the psychoanalytically informed thinking of Carl Gustav Jung and Wilhelm Reich on mass psychology in totalitarian regimes. ${ }^{16}$

According to Le Bon, who was profoundly influenced in this respect by the work of Hippolyte Taine, the French Revolution was a crucial event that required an explanation capable of penetrating the otherwise "mysterious workings of chance." ${ }^{17}$ Indeed, Le Bon asked himself, in terms similar to Tackett, how it was possible that "peaceable intelligent bourgeois," on becoming representatives of the people, could on the one hand approve decrees imbued with civility and ideas of progress (such as the introduction of the decimal metric system and the opening of the Grandes Écoles) and, on the other, vote in favor of "barbarous" measures

12. Georges Lefebvre, The Great Fear of 1789: Rural Panic in Revolutionary France [1932], trans. Joan White (Princeton: Princeton University Press, 1982); Lefebvre, "Revolutionary Crowds" [1934], in New Perspectives on the French Revolution: Readings in Historical Sociology, ed. Jeffry Kaplow (New York: John Wiley and Sons, 1965), 173-90.

13. George Rudé, The Crowd in the French Revolution (Oxford: Clarendon Press, 1959); Rudé, "Les débuts d'une idéologie révolutionnaire dans le petit peuple urbain en 1789. Esquisse d'une étude comparée," in Die Franะösische Revolution, zufälliges der notwendiges Ereignis, ed. Eberhard Schmitt and Rolf Reichardt, 3 vols. (Munich: Oldenbourg, 1983), 1:30-39.

14. Gustave Le Bon, The Crowd: A Study of the Popular Mind [1895] (New York: Macmillan, 1896). Lefebvre's essay "Revolutionary Crowds" is, in a certain sense, an answer to-and refutation of-Le Bon's book.

15. Gabriel Tarde, The Lawes of Imitation [1890], trans. Elsie Clews Parsons (New York: Henry Holt, 1903); Tarde, L'opinion et la foule (Paris: F. Alcan, 1901).

16. Carl Gustav Jung, "The Role of the Unconscious," in The Collected Works of C. G. Jung, vol. 10, Civilization in Transition, ed. Herbert Read, trans. R. F. C. Hull, 2nd ed. (Princeton: Princeton University Press, 1970), 3-28; Wilhelm Reich, The Mass Psychology of Fascism [1933], trans. Vincent Carfagno (New York: Farrar, Straus, and Giroux, 1970).

17. Gustave Le Bon, La Révolution française et la psychologie des révolutions (Paris: Flammarion, 1912; repr. 1916), iv-v. These remarks appear in the preface, which was not included in the English translation of this volume: Le Bon, The Psychology of Revolution, trans. Bernard Miall (New York: G. P. Putnam’s Sons, 1913). 
(one only has to recall the executions of poets such as André Chénier and scientists such as Antoine Lavoisier, or the destruction of the tombs in the basilica of SaintDenis). ${ }^{18}$ In his opinion, the explanation could be found in the opposition between rational logic, which prevails in ordinary times, and other (affective, collective, and mystic) forms of logic that come into play in "extraordinary" times. It was because emotions such as hatred or enthusiasm destroy the individual's psychological unity and rational control that the multiple and conflicting personalities lurking beneath the surface were able to emerge. ${ }^{19}$

It is curious how far this theoretical apparatus, fundamentally turned toward reactionary ideological ends, resembles (possibly as a result of a shared Durkheimian influence) Sophie Wahnich's complex and philosophically engaged attempt to reaffirm the relevance of the Revolution by invoking a mass emotional dynamic. ${ }^{20}$ Starting out with the judicious intention of freeing the French Revolution from the unjust accusation (attributable to Furet) that it was the original source of the horrors of twentieth-century totalitarianism, Wahnich's essay ultimately endorses a position that exonerates revolutionary violence as a whole, and apparently suggests, moreover, that it should be considered "one and indivisible." Emotions and the way they transform individuals are thus enlisted to justify not only the spontaneous atrocities perpetrated by armed crowds, but also the terrorist behavior of both the people and the institutions. While it was possible for Albert Mathiez, writing in 1922, to describe the Terror as nothing less than the "red crucible in which the future democracy was elaborated," today's public opinion is characterized by a different sensibility toward bloodshed and a tendency to voice moral condemnation rather than make historical judgments-thus complicating the task of understanding the revolutionary drama. Indeed, in order to comprehend the latter, writes Wahnich, we need to analyze the new symbolic system that came into being, by reappraising the sacred dimension in revolutionary politics. ${ }^{21}$ Arguing against Patrice Gueniffey and his analysis of revolutionary rhetoric as the driving force behind a drift toward indiscriminate violence, ${ }^{22}$ Wahnich puts forward the hypothesis of an "emotional economy" centering on a collective subject-the people-reacting with acts of restorative and punitive vengeance against the feelings of outrage and horror inspired by the enemy (whether external threats or the enemy within). ${ }^{23}$ This was a form of "revolutionary justice," defending not

18. Le Bon, La Révolution française, v.

19. In turn, explanations of the actions of the revolutionary crowd need to take into account the role of the surrounding environment, which creates an overriding mindset capable of imposing itself on individuals and dominating them. Thus, people sometimes spread rumors simply because people spread rumors, and people rise up in revolt because everyone is in revolt. See Le Bon, La Révolution française, 61 and 66.

20. Sophie Wahnich, In Defence of the Terror: Liberty or Death in the French Revolution [2003], trans. David Fernbach (London: Verso, 2012).

21. Ibid., 5-7.

22. Patrice Gueniffey, La politique de la terreur. Essai sur la violence révolutionnaire, 1789-1794 (Paris: Fayard, 2000).

23. Sophie Wahnich, "De l'économie émotive de la Terreur," Annales HSS 57, no. 4 (2002): 889-913. 
an individual but a sovereign people; it was roused to action by the-conscious or unconscious-disruption of the sacred balances that regulated the collective identity of the populace.

Despite a powerful theoretical apparatus largely grounded in the thinking of Giorgio Agamben, Wahnich's description of the people ultimately bears a curious resemblance to Jules Michelet's classic analysis, ${ }^{24}$ portraying it as an animate and sentient subject possessing a clearly defined moral vision oriented toward preserving "Public Safety," even if this involved the sacrifice of the individual self-that is, of the physical body. ${ }^{25}$ The Revolution's leaders are thus reduced to mere spokespeople, and Danton's famous "let us be terrible, to save the people from being so" becomes the expression of this community-wide emotional response, born of a need for vengeance and aimed at restoring the violated sanctity of the people envisaged as a collective subject. ${ }^{26}$

Confronted with these clearly opposed but quite radical historiographical uses of the emotions, Tackett adopts a flexible, moderate approach that does not claimnor indeed seek-to explain everything. His survey is based on a corpus comprising letters, diaries, and printed newspapers, containing accounts drawn up as close as possible to the events of the Revolution. Working from these documents, he analyzes the emotions of the revolutionary elite in exactly the same way as earlier historiography had examined the psychology of the masses. ${ }^{27}$ His hypothesis is that the emotional transformations revealed in these accounts, written in the heat of the moment and in reaction to traumatic events, can serve as a guiding thread through the sequence leading to the Terror and ultimately help to "explain" it. Tackett points to the numerous expressions of emotion, present in almost every line, and underscores the volatility manifested in their rapid alternation between joy and anguish, fraternity and hatred. ${ }^{28}$ This emotional hypersensitivity was moreover highly permeable to the spread of unverified information and false news. ${ }^{29}$ Though such rumors mainly originated in working-class neighborhoods, they also spread rapidly among the social elites. The emotions that coalesced around themparticularly fear, suspicion, and anger-thus became collective phenomena, leaving abundant traces in the writings of patriots. They were all the more remarkable when their efficacy was measured not only by the yardstick of the immense enthusiasm

24. Jules Michelet, The People [1846], trans. G. H. Smith (New York: D. Appleton and Co., 1866).

25. Wahnich, In Defence of the Terror, 66-67. In substance, this alternative is expressed in the revolutionary slogan "Liberty or Death." The appropriation of sovereignty by the people effectively demands the translation of its emotional norms into laws: when the political class is incapable of listening to the voice of the people, the result is the direct affirmation of justice and its restoration through violence. State Terror can therefore be understood as an attempt to contain violence, and the Law of Suspects (September 17, 1793) can be considered as a means of "suspending the mimetic law of spilled blood."

26. Wahnich, In Defence of the Terror, chap. 1.

27. Tackett, The Coming of the Terror, 5.

28. Ibid., 6.

29. Ibid., 124-25. 
and powerful sense of fraternity apparent from the outset of the Revolution, but also by that of the high expectations of a new world, a world never before seen or even really desired, embodying a new sense of the possible. ${ }^{30}$ Joseph-Yves Roüault de Cosquéran, a lawyer and later deputy to the Convention, thus described the climate of excitement combined with solidarity that made the night of August 4, 1789 , possible by stating that "woodcutters had brought down an entire forest in a few hours." 31 This boundless confidence in the malleability of the social world and the "supernatural effects' of liberty and equality" offers, according to Tackett, the most eloquent example of the "transformative power of emotion." 32

Very soon, however, this confidence came to be pervaded with anxiety, a heightened sense of insecurity, and ultimately with fear: fear of invasion by an external enemy, of chaos, of anarchy, fear of revenge by counterrevolutionaries, and, above all, fear of conspiracies. Dread of the enemy within began to mount, identified with the image of the conspirator wearing the mask of patriotism projected by JeanPaul Marat, and a spate of denunciations ensued. ${ }^{33}$ In a climate of suspicion, there thus emerged a sort of "everyday terror," in which everyone was at once spy and spied on. ${ }^{34}$ In his endeavors to attribute the emotional repertoire of the revolutionary elites a decisive role in the process leading to the Terror, Tackett devotes most of his analysis to the conspiracy mindset, the recurrent fear of-and even tangible obsession with - plots hatched by enemies of the Revolution. ${ }^{35}$ Here again, we see the influence of the debate instigated by Richard Hofstadter in his now-classic essay on the "paranoid style" in politics, a concept which at one time met with considerable success in American political sciences, and has recently come back into fashion. ${ }^{36}$ According to Tackett, this pattern is particularly appropriate for the French Revolution, as it was less a question of individual reactions to unconnected counterrevolutionary plots than the spread of a collective, obsessive mindset, centered on a

30. Robert Darnton, The Kiss of Lamourette: Reflections on Cultural History (New York: Norton, 1990). On this particular episode, see Caroline Chopelin-Blanc, "Le "baiser Lamourette' (7 juillet 1792)," Annales historiques de la Révolution française 335 (2009): $73-100$.

31. Quoted in Tackett, The Coming of the Terror, 62.

32. Ibid., 7 and 62.

33. Ibid., 128 and 133. In February 1792, Desmoulins was the author of a pamphlet entitled Jean-Pierre Brissot démasqué.

34. Tackett, The Coming of the Terror, 135.

35. Timothy Tackett, "Conspiracy Obsession in a Time of Revolution: French Elites and the Origins of the Terror, 1789-1792," American Historical Review 105, no. 3 (2000): 691-713; Tackett, "Collective Panics in the Early French Revolution, 1789-1791: A Comparative Perspective," French History 17, no. 2 (2003): 149-71.

36. Richard Hofstadter, "The Paranoid Style in American Politics," Harper's Magazine, November 1964, 77-86, reprinted in The Paranoid Style in American Politics and Other Essays (New York: Knopf, 1965). For a current and global view of the debate, see the dossier entitled "Vous avez dit 'complot'?" in Le Monde diplomatique 62/735 (2015): $17-23$. 
belief in the existence of a single, omnipresent grand conspiracy. ${ }^{37}$ Belief in a generalized counterrevolutionary conspiracy thus emerged and spread over time, particularly after Louis XVI's flight from Paris to Varennes-a pivotal event that Tackett analyzed in an earlier study. ${ }^{38}$ It became definitively entrenched once France was encircled by the armies of the European powers and the uprising in the Vendée had broken out. At "a deeply troubling and frightening time," the irresistible force of this belief terrorized not only the masses but also the revolutionary elites. ${ }^{39}$ Tackett therefore concludes that it was terror inspired by the idea of conspiracy that forged the terrorist mindset through the demonization of the counterrevolutionary plotter, a figure in which all the fears of a society were condensed. The American historian quotes appositely from Shakespeare: "In time we hate that which we often fear."

There thus arose a veritable culture of suspicion which, in the context of political struggle between warring factions, mutated into a demonization of the other, the political adversary, now described as an enemy of the Revolution. ${ }^{41}$ Like émigré nobles ${ }^{42}$ or refractory priests, such enemies needed to be expelled from the nation and civil society (later, the conviction that they "want[ed] our blood" would mean that they were physically eliminated). The conflict between the different revolutionary factions thus assumed the characteristics of a relentless struggle for survival. Once it was felt that, as Jean-Marie Collot d'Herbois claimed, the rights of man only applied to citizens and not to counterrevolutionaries ${ }^{43}$ the accusation of being a hidden conspirator deprived the individual of all juridical protection, and turned political rivalry into a process of bloody elimination. ${ }^{44}$ In his last letter to his wife, Camille Desmoulins wrote that the Revolutionary tribunal had only asked him a single question: Had he conspired against the Republic? ?5 $^{45}$

In his conclusion, however, Tackett qualifies his central thesis, stating that "the appearance of a terrorist mindset cannot be explained in a one-dimensional manner." ${ }^{46}$ Among the different contributory causes, he quite rightly mentions the collapse of traditional principles of authority, the active role of the politicized masses

37. This perspective was not the product of deranged minds. Tackett points out that of the thirty-two future representatives of the Third Estate in the Estates General who wrote pamphlets during the period immediately preceding its inauguration, only one (Robespierre) showed signs of a paranoid analytical style. The Coming of the Terror, 137. 38. Tackett, The Coming of the Terror, 7. See also Tackett, When the King Took Flight (Cambridge: Harvard University Press, 2003).

39. Tackett, The Coming of the Terror, 1.

40. Ibid., 139-41, here p. 140. Fear is at the center of the analysis offered in David Andress, The Terror: The Merciless War for Freedom in Revolutionary France (New York: Farrar, Straus, and Giroux, 2006).

41. Tackett, The Coming of the Terror, 158.

42. Thomas E. Kaiser, "Nobles into Aristocrats, or How an Order Became a Conspiracy," in The French Nobility in the Eighteenth Century: Reassessments and New Approaches, ed. Jay M. Smith (University Park: Pennsylvania State University Press, 2006), 189-224.

43. Tackett, The Coming of the Terror, 303.

44. This extermination also affected elected representatives. See Michel Biard, La liberté ou la mort. Mourir en député, 1792-1795 (Paris: Tallandier, 2015). 
seeking revenge for the oppression to which they had been subjected under the ancien régime, the idealized vision of the people embodied in the figure of the sans-culottes, and the creation of what he calls, borrowing an expression from Barbara Rosenwein, "an emotional community," ${ }^{7}$ in which the sentiments of the masses and those of the elites gradually merged.

This balanced approach is sustained by a complex, articulate narrative style that eschews all simplification. Indeed, The Coming of the Terror is, in its way, a grand history of the French Revolution, written, as is to be expected of its author, in a careful, measured, perceptive fashion. It is a history with which in large part I agree, and it contains thoroughly innovative analyses of both the decadence of political authority and the process of decentralization that began in $1789 .{ }^{48}$ Nevertheless, although the perspective adopted to "explain" the Terror is the product of original research exploiting rich sources hitherto unused from this standpoint, it is overall only partially convincing.

Indeed, in many cases the reactions of the individuals within the selected sample are hardly surprising. It is difficult to imagine that private correspondence during these years of war and profound social and political upheaval would not express feelings of joy, frustration, disillusion, and fear. As regards the central hypothesis-that of a terrorist mindset born of the obsession with conspiracyTackett presents material which suggests that this fixation, although a central component of revolutionary rhetoric, needs to be viewed with caution. Firstly, not all the conspiracies were imaginary. Tackett even draws up a detailed list of those that really existed and were "revealed," as it were, by the betrayal of their principal protagonists: think of Lafayette, Dumouriez, and-after the discovery of the famous papers in the hidden safe-Mirabeau and the sovereign himself.

Above all, an obsession with conspiracy was not so much a sort of virus, infecting and poisoning republican orators, as a field of debate and conflict. It was a political weapon present at the very heart of all demagogic political rhetoric, and was consciously exploited by all sides. For instance, in the account that it published on the morning of October 6,1789 , of the dramatic invasion of the château at Versailles and the murder of some royal bodyguards-one of the most obscure incidents in the Revolution-the Courrier de Provence attacked "those suspicious minds who s[aw] mystery wherever they look[ed]" and discovered, "according to the whim of their imagination, armies and plotters who, with the ease of our novelists, appear[ed] to have seen everything and to have been able to go wherever they wished." ${ }^{49}$ The same case prompted Mirabeau to denounce the concoction of untrue conspiracy theories, in an attempt to absolve himself from an accusation that had arisen from his ambiguous relations with the Duke of Orléans. For months, the arcades of the Palais-Royal had been abuzz with rumors concerning a projected

47. Barbara H. Rosenwein, Emotional Communities in the Early Middle Ages (Ithaca: Cornell University Press, 2006).

48. Tackett, The Coming of the Terror, 71-77.

49. Quoted in Louis de Loménie, Les Mirabeau. Nouvelles études sur la société française au XVIII siècle (Paris: Dentu, 1879-1891), 4:485. 
march on Versailles, and it had become public knowledge after a first unsuccessful attempt prompted the deputy Guillaume Goupil de Préfelne to make a speech to the National Assembly on August 31, unleashing his famous invective with its allusion to Sallust: "Catilina is doing his utmost to stir up sedition. Catilina is at our gates. ${ }^{50}$ Conversely, mention of a plot could be a strategy aimed at concealing an individual's own responsibility: on May 27, 1792, for instance, Jacques-Pierre Brissot denounced a conspiracy in order to divert attention from the disastrous effects of his call for war. ${ }^{51}$ On yet other occasions, the denunciation of a foiled plot could serve to legitimize an illegal act: the Directory's coups of 18 Fructidor Year V (September 4, 1797) and 22 Floréal Year VI (May 11, 1798) were justified by the need to defend the Republic against, in the former case, an Anglo-monarchical plot, and, in the latter, an anarchist conspiracy. ${ }^{52}$

This is not to deny that fear of conspiracies could produce powerful emotional reactions. Indeed, far from it, which is why it is important to study the ways in which this theme was exploited in political rivalry. Underestimating this dimension would lead to the separation of one component of public rhetoric from the broader context of the political struggle of which it was a part, with the obvious risk that individuals would be considered mere passive receptors, driven by uncontrollable emotions possessing an independent existence and a capacity for autonomous action. It may be helpful to recall that individuals access knowledge of events, in particular of traumatic events, through constructed representations that are debated in the public sphere. Moreover, not only do emotions belong to a shared culture, but the ways in which they can be aroused, inflamed, and exploited depend on specific rhetorical capabilities. Precise messages are thus consciously diffused through different media channels in order to activate discussion spaces in the public arena that are polarized along identity-based lines. It should not be forgotten that, well before the twentieth-century invention of the Gallup poll and the spin doctor, the battle for political power was also-and sometimes even primarily-played out though the control and manipulation of public opinion. In this struggle between opposing propagandas, the goal was not solely to persuade but also to engage emotionally, to foster a sense of belonging, to play on dormant fears, and to encourage feelings of love and hate. In politics, emotions are not simply experienced; they are also constructed.

\section{A Philosophers' Revolution?}

The conception of the Revolution proposed in Jonathan Israel's Revolutionary Ideas offers a quite different perspective. Whereas Tackett seeks to deepen our knowledge of the personal, emotional, and affective experience of the actors of the Revolution, Israel focuses his attention not on people, but on the ideas that

50. Ibid., 498.

51. Tackett, The Coming of the Terror, 176. 
inspired them..$^{53}$ In a way, this book represents a continuation of the three works he has already devoted to the history of the Enlightenment, a fourth (though perhaps not final) volume that lies within the framework of a more global effort of reconstruction..$^{54}$

Israel's hypothesis is unhesitatingly founded on a criticism of the scholarly consensus that the causes of the French Revolution were numerous and varied. In his opinion, it is high time that this consensus was debunked, as the Revolution had a single, clearly identifiable origin: the dissemination, among one section of the French ruling class, of the ideas of the radical Enlightenment ${ }^{55}$-a system of thought which he described in an earlier work, provoking vigorous scholarly debate. ${ }^{56}$ It was not, he argues, the Enlightenment as a whole that led to the Revolution, but rather a single and particular current within it, corresponding to such famous figures as Denis Diderot, the Baron d'Holbach, and Claude-Adrien Helvétius. For Israel, the ideas of the radical Enlightenment-democraticrepublican and atheist-materialist in nature-were "incontrovertibly the one 'big' cause of the French Revolution," ${ }^{57}$ since they alone were capable of inspiring and equipping the leaders of the Revolution on a political level as well as in terms of philosophy and logic.

The British historian does not deny that the monarchy underwent a financial crisis, but argues that once the Estates General had been summoned, it was the implementation of the ideas of the radical Enlightenment, and this alone, that made the massive transformation of the social order possible. What Jacques Necker called "l'esprit philosophique" 58 was thus responsible for the greatest upheaval ever experienced at that time, a series of events described by Israel as a process of emancipation, democratization, and social renewal grounded in the recognition of human rights. ${ }^{59}$ The principal consequence of such an approach, which is profoundly different from Roger Chartier's perspective on the intellectual sources of the French

53. See Tackett, The Coming of the Terror, 343: "Unlike many revolutions of late-modern history, the events in France were not based on a pre-existing, well-defined ideology. They did not represent a simple appropriation of one strand or another of the philosophy of the Enlightenment."

54. Jonathan Israel, Radical Enlightenment: Philosophy and the Making of Modernity, 1650-1750 (New York: Oxford University Press, 2001); Israel, A Revolution of the Mind: Radical Enlightenment and the Intellectual Origins of Modern Democracy (Princeton: Princeton University Press, 2010); Israel, Democratic Enlightenment: Philosophy, Revolution, and Human Rights, 1750-1790 (New York: Oxford University Press, 2011).

55. Israel, Revolutionary Ideas, 29.

56. Israel, Radical Enlightenment; Antoine Lilti, "Comment écrit-on l'histoire intellectuelle des Lumières? Spinozisme, radicalisme et philosophie," Annales HSS 64, no. 1 (2009): 171-206. See also Keith Baker's review of Israel's Democratic Enlightenment, published in H-France Forum 9, no. 1 (2013): 41-56, and at http://www.h-france. net/forum/forumvol9/Israel3.pdf. For a fairly complete overview of the criticisms, see Jonathan Israel, "How to Write the Intellectual History of the Enlightenment - and the Revolution: A Critical Foray," Rivista storica italiana 124, no. 3 (2012): 1049-91.

57. Israel, Revolutionary Ideas, 708.

58. Quoted in ibid., 14.

59. Ibid., 13. 
Revolution, ${ }^{60}$ is the claim that the revolutionary experiment was not particularly innovative, since in substance it was nothing more than the "implementation" of a preexisting philosophical system. Not only did the revolution in ideas predate the revolution of fact, ${ }^{61}$ but the latter was in a way part of the former. In sum, Israel considers that the collapse of the ancien régime can be attributed solely to the diffusion of "philosophy," understood as the radical Enlightenment current that criticized and rejected the existing social order.

While Tackett sees the Revolution as an unexpected upheaval, the dawn of a hitherto unthinkable new world, for Israel it represents an epiphany, the materialization of a philosophical spirit long diffused throughout French society. He is well aware that the broader public's knowledge of the works of the philosophers was limited, and confined mainly to their literary production. ${ }^{2}$ Yet he remains convinced that there existed an implicit and general tendency in French public opinion that caused it to adhere, as early as 1788 , to the trend toward democratic republicanism, ${ }^{63}$ dominated and piloted by an active, militant minority imbued from the outset with radical Enlightenment principles. Beyond this general influence on events, Israel also believes he has been able to identify the group of philosophers and intellectuals who guided the Revolution from its outbreak. Yet, as Tackett rightly points out, the revolutionary elite as a whole was still monarchist in 1789 , and Israel has to go to considerable lengths to identify a handful of minor intellectuals whom he can describe as "near-republican." "Ultimately he names three "champions" of the radical Enlightenment whom he considers to be, if not out-and-out republicans, at least republicans in the making: Mirabeau, Lafayette, and Emmanuel-Joseph Sieyès. ${ }^{65}$

However, the convictions and political activity of these three personalities do not justify this interpretation. Mirabeau's ambition was to become a minister of the Crown, and indeed he eventually became a secret counselor to the king. Far from being a campaigner for the republican faction, Sieyès figured among the founders of the Society of $1789 .{ }^{66}$ He played a leading role in some of the most sensational intrigues engineered by the constitutional monarchist party in the Assembly, where he identified with the political group known as the Plain. As for Lafayette, if in Parisian salons he sometimes cultivated the "republican" image that tallied with his profile as a fighter for "American" liberty, for an entire decade his political action remained grounded in the principles of constitutional monarchy. If Israel sometimes strains his argument, this is because his expository model has a tendency to strongly differentiate good from evil, and to make a cut-and-dried distinction

60. Roger Chartier, The Cultural Origins of the French Revolution, trans. Lydia G. Cochrane (Durham: Duke University Press, 1991).

61. Ibid., 38.

62. Tackett, The Coming of the Terror, 32-33.

63. Israel, Revolutionary Ideas, 703.

64. Ibid., 26.

65. Ibid., 209.

66. Mark Olsen, "A Failure of Enlightened Politics in the French Revolution: The Société of 1789," French History 6, no. 3 (1992): 303-34. 
between what might be termed the "good guys" and the "bad guys." He considers the radical Enlightenment as progressive, whereas he sees the current represented by Montesquieu, Voltaire, and John Locke as largely conservative and backwardlooking. Moreover, he applies the same binary-not to say Manichean-logic to the Revolution as a whole: on one side stand the proponents of philosophical reason, identified with certain crypto-republicans who would later form the Brissotin group; on the other stand the adepts of the general will (la volonté générale) as defined by Rousseau, typified by Maximilien Robespierre and the future Jacobin inner circle. ${ }^{67}$ Israel's position is unambiguous: the former were the defenders of the rights of man, the true democrats, the real supporters of republican ideas, and the only authentic revolutionaries (who were certainly not the peasantry nor even the sans-culottes ${ }^{68}$ ). The latter, on the other hand, were the representatives of a populist ideology so authoritarian as to become despotic, and they alone were responsible for the derailment of the Revolution.

According to Israel, then, France was divided at this crucial juncture by a profound schism, a rift that was at once philosophical, moral, and personal, and which pitted the Jacobins ${ }^{69}$ against the Brissotins. ${ }^{70}$ Here, too, the interpretation appears forced. The line separating the two groups, their respective ideologies, and the individual behavior of their members is far less clear than the author claims. Brissotin policy on the monarchy was radically different from what might be expected of "uncompromising" republicans. Did they not set up a dense network of contacts immediately after the king's flight to Varennes in order to present themselves as the interlocutors for and defenders of the Crown, with the aim of establishing Dumouriez in the role of mediator previously occupied by Lafayette? Did they not offer the king a sort of guarantee at a time when his position had been considerably weakened by the appointment of three members of their group to the government? After August 10,1792, was it not their group that gambled on the sovereign's "suspension" rather than the immediate fall of the monarchy? Lastly, during the troubled period of the king's trial, did their indecision and maneuvering not give everyone (including the sovereign) the impression that they were trying to gain time, and that the proposal to consult the people was actually a ploy aimed at offering the king a way out?

Even the unfortunate decision to go to war, which was probably the main political battle won by Brissot and his friends, was made in close collaboration with the Crown. In this connection, it must be stressed that Israel unhesitatingly embraces the Girondin point of view that military ventures were a means of disseminating democratic ideals and the philosophy of the rights of man throughout Europe. This position takes into consideration neither the enormous human

67. Israel sees a total opposition between the two factions and refers to "the ceaseless battle waged unremittingly ... between the Revolution of Reason and the Revolution of the Will": Revolutionary Ideas, 21.

68. Ibid., 695.

69. On the need to transcend a monolithic vision of the Jacobin group, see Pierre Serna, Antonelle. Aristocrate révolutionnaire, 1747-1817 (Paris: Éd. du Félin, 1997).

70. Israel, Revolutionary Ideas, 287. 
and economic cost of the escalating war, occasioned by raising the first mass army, nor the rejection of the new revolutionary ideas in several parts of Spain and Germany. Indeed, such is the historian's adherence to the Girondin perspective that he does not hesitate to subscribe to the polemical judgment, publicly expressed by Jean-Baptiste Louvet, that "there [were] only two parties in France": "the first [the Girondins] composed of philosophers; the second [the Mountain] of thieves, robbers, and murderers." 71

Israel convincingly demonstrates that these political groupings were not composed solely of committees of parliamentarians, but flourished and were sustained by one of the great inventions of revolutionary politics: press freedom, a fundamental democratic principle which he tenaciously defends. So doing, he does not take into account the reasonable objections of those, whether "Monarchiens" or "Feuillants," who affirmed that unlimited freedom of the press meant accepting a state of permanent agitation. While constitutional monarchical theses are generally viewed by Israel as backward-looking, and hence of negligible interest, he does not really examine in depth the Girondins' wavering between the uncritical glorification of absolute press freedom and their repeated attempts-particularly when they felt specifically targeted-to curb the publication of radical newspapers such as L'ami du peuple.

In the face of considerable difficulties, the deputies of the Constituent and Legislative Assemblies learned that the new revolutionary politics was not just a matter of parliamentary balances: it also required an ability to obtain support for the elected chamber from the newly emerging power of public opinion, expressed in the numerous pamphlets of various political orientations circulating among the populace. The links between the spheres of the Assembly and the press were well known, and meant that political hegemony was not simply the product of a numerical majority within an all-powerful legislature, but also depended on an ability to bring the weight of public opinion to bear on parliamentary debate. The situation was, of course, further complicated by the counter-power formed by the Paris Commune and the sections, which claimed to express and represent the mood of public opinion or, as it was termed at the time, the "people." The Commune and sections undertook various actions aimed at influencing decisionmaking, the most spectacular of which involved the threat posed by mass rallies and the presence of noisy supporters in the public galleries of the Assembly. Here again, the personal links between section leaders and parliamentary groups were clearly identifiable. ${ }^{72}$

One strand of historiography inspired by conservative or reactionary values has simplified the problem by foregrounding the theme of the rabble-rouser, that is, the action of individuals in the pay of influential groups capable of stirring up civil disorder. This kind of ploy was well attested under the ancien régime and may

71. Jean-Baptiste Louvet, Mémoires de J.-B. Louvet ... de la journée du 31 mai 1793 (Paris: Librairie historique, 1821), 1:107, quoted in Tackett, The Coming of the Terror, 231. 
have played a part in the first stages of the Revolution (Lafayette was convinced that "the populace was steered by an invisible hand" during the events of October 5 and $\left.6,1789^{73}\right)$. But the importance of these figures should not be exaggerated. Israel emphasizes the masses' spontaneity of action and defines the agitators who harangued the crowd during the first days of the Revolution as "demi-philosophes." For the period 1792-1793, however, he highlights the political control that they exercised and mentions the claque of sans-culottes hired to support Robespierre. ${ }^{75}$ Such a point of view seems reductionist: the Revolution entailed a huge broadening of political participation and consequently led to the construction of new realms of socialization, original methods of consensus building, and modern forms of political engagement. The construction of a political consensus during the revolutionary period thus involved very particular modalities which needed to take account of all these components, and others besides: the role of the court and the executive until August 10,1792, and that of the army thereafter.

Israel shows scant interest in these concrete forms of the political dialectic, which he reduces to a struggle between competing philosophies related to principles unconnected with the human dimension. Indeed, he considers the constitutional monarchist party the representative of a conservative conception of the Enlightenment of Voltaire, or even worse, of Montesquieu, defending a hackneyed balance destined to be swept away by the republican journée of August 10. Even revolutionary violence is presented in a schematic, polarized way. On one side, we have a democratic insurrection, which Israel sees as the expression of Girondin aspirations for regime change brought about by the masses, and whose violent nature is downplayed and marginalized as though it were merely collateral damage; on the other, the September massacres and their attendant horrors are attributed, without convincing evidence, to the effects of tight Jacobin political control. ${ }^{76}$

The problem of the Terror is thus solved at its source. According to Israel, there was an illiberal authoritarian component in the Revolution, epitomized by Jacobinism, to which the resultant litany of tragic events must be attributed in its entirety. Here too, the crux of the matter lies in its theoretical origins: in substance, the unfortunate outcomes of the Revolution derived from Rousseau and from an ill-conceived application of his theory of the "general will." They also originated in a form of blind, moral puritanism that led to an excessive readiness to exalt the role of personal virtue and maintain a certain religiosity. Of course, Robespierre is the embodiment of all these ideological features that went to make up a sort of crude, chauvinistic, anti-Enlightenment "Rousseauism in action." His hegemony is presented as a sort of arbitrary dictatorship, or even as a tyranny that was antimonarchical, antirepublican, and anti-sans-culotte-in short, antirevolu-

73. Albert Mathiez, "Étude critique sur les journées des 5 et 6 octobre 1789," Revue historique 23/67 (1898): 241-81, here p. 256.

74. Israel, Revolutionary Ideas, 58.

75. Ibid., 283.

76. Ibid., 271. 
tionary. ${ }^{77}$ The expulsion and later elimination of the Brissotins is thus described as the Incorruptible's "putsch." ${ }^{\text {" I }}$ Israel is not afraid to defy anachronism and blame the famous lawyer from Arras not only for the failures that can legitimately be laid at his door, but also for the future totalitarianism of the twentieth century: using an expression that will certainly raise eyebrows, he describes Robespierre's political activity as "an authoritarian populism prefiguring modern fascism." 79

In sum, Israel considers that there was not one French Revolution but three: the authentic, republican, democratic, Girondin revolution, and two pseudorevolutions consisting of the constitutional monarchical version, inspired by the English model, and the despotic revolution of the Jacobin dictatorship. It was the last of these that put an end to the authentic revolutionary experiment, even if, after the demise of this dictatorship on 9 Thermidor Year II (July 27, 1794), it was once again the ideologues, described as resuscitated Girondins, who provisionally took up the torch of democracy.

\section{A Revolutionary Anthropology?}

Whereas Israel consistently situates the Revolution in the field of philosophy and interprets its conflicts as theoretical disputes, Haim Burstin's Révolutionnaires offers a close-up view of the revolutionary experience in a study which he describes as "anthropological." The term is not chosen at random. For Burstin, the task of recovering for today's reader the true meaning of the Revolution-that creative storm which led to both unspeakable traumas and massive changes-involves a journey into a different world and an encounter with an unfamiliar civilization. This is why, borrowing an expression from Alphonse Aulard ("to understand it, one must love it" $\left.{ }^{\prime 0}\right)$, the Italian historian sets out as a precondition the need for an empathic, or at least non-hostile, attitude toward the revolutionary phenomenon. Admittedly, things have moved on from the time when uncritical militant glorification could forge deep-rooted identifications. Nevertheless, for Burstin, a certain degree of adherence to the revolutionary universe is a necessary basis for the critical curiosity that makes it possible to transcend the hostile prejudices so common todayprejudices that consider the Revolution, anachronistically, as "an original sin responsible for the totalitarianisms to come." ${ }^{81}$

Thus, like Tackett and Israel, Burstin sets himself the difficult task of restoring contemporary meaning to the Revolution. To this end, he proposes a sort of "participant observation" with a view to honing in not on the Revolution as a whole, but on the men and women who drove it forward-in sum, the revolutionaries themselves. An undertaking of this nature implies a rejection of our false familiarity with

77. Ibid., 507 and 566: "In short, Robespierre comprehensively abjured every component of the Revolution apart from Rousseau and himself."

78. Ibid., 420.

79. Ibid., 695 .

80. Burstin, Révolutionnaires, 8.

81. Ibid., 7. 
the period, its participants, and their acts, a rejection, that is, of the facade put up by the Revolution itself and its mythology. The aim is immersion, via the anthropological approach, in the revolutionary experience. ${ }^{82}$

In order to probe the lived experience of the actors-not just the leading roles but also the humble extras-one has to get to the heart of the mechanisms at play in the Revolution. ${ }^{83}$ Now that the revolutionary fury has abated, it is time to make a calmer, though not detached, appraisal aimed at understanding how the revolutionary torrent was able to influence and reshape the personalities of individuals. ${ }^{84}$ With this approach, which parallels Tackett's in certain respects, Burstin seeks to focus on the psychological register, and in particular on the emotional disposition mobilized through active participation in the Revolution. However, he considers the revolutionary experience to be something radically different from the experience of normal life. It is even one of the fundamental conditions of the march of history, and its specificity must be understood in its own terms. It is characterized by an extraordinary impetuous energy which was intended to form, so to speak, "an assault upon heaven" and rebuild society from scratch, making a tabula rasa of the past. This fed a utopian ardor founded on the idea of regeneration, an acceleration that translated into the educational desire to forge a new kind of individual and create a revolutionary personality. ${ }^{85}$

According to Burstin, then, the Revolution in action was a unique experience founded on the creation of a feeling of belonging, a revolutionary "self" which, once all links with the past had been severed, would project the individual toward a future yet to be invented. This "new Man" was accompanied by a veritable republican habitus, a secular transposition of the religious habitus. ${ }^{86}$ In this experience, centered on "enthusiasm" and a sort of participatory fever, we can observe a new sense of time, which took the form of an acceleration of the pace of politics and a different, inclusive way of engaging with it. ${ }^{87}$ There thus arose new linguistic and discursive practices which, taken as a whole, made up a lexicon of liberty and democracy. There also emerged a new political sociability, centered on the Assembly, that amounted to both a schooling in democracy and, ultimately, a veritable civilization.

One effect of this approach is that the Revolution's center of gravity is shifted downstream, during the republican phase. If, at the core of the revolutionary experience there lay a "republican" mentality that was to become a lifestyle and a worldview, then the first part of the Revolution can be seen as a long learning curve

82. Burstin refers to Bronisław Malinowski, but it is interesting to wonder what might have happened if he had decided to engage with Clifford Geertz and his concept of "thick description."

83. Burstin, Révolutionnaires, 12.

84. Ibid., 9.

85. Ibid., 33 .

86. Burstin refers to the work of Dominique Julia. On the theme of religious rootedness and revolutionary transformation, see Lucien Jaume, Le religieux et le politique dans la Révolution française. L'idée de régénération (Paris: Presses universitaires de France, 2015). 87. Alexandre Escudier, "Le sentiment d'accélération de l'histoire moderne: éléments pour une histoire," Esprit 6 (2008): 165-91. 
paving the way for what was to follow, ushered in by the journée of August 10 . More generally, if the "new Man"-the revolutionary, the republican-is central to the Revolution, the danger is that he will be seen not merely as a figure that emerged with difficulty in particular conditions of conflict and political strife, but rather as a project that homogenized behaviors which, both before the journée of August 10 and after Thermidor, were in reality far more complex and diverse, not to say divided and sometimes antagonistic. Despite Burstin's intentions, the anthropological gaze in Révolutionnaires gives way to a process of abstraction built out of ideal types grounded more in sociology than anthropology. Moreover, in focusing on the Revolution as a world of its own, one that is special and apart and inhabited by a single type of subject - the revolutionary-we lose sight of all the contradictions that marked its path, particularly the factional struggles and civil war.

The risk of this perspective is that only the two-year period from the establishment of the Republic to Thermidor is considered the unique and "true" revolution. Burstin is well aware of this, as evidenced by his analysis of the practices of the various assemblies, a type of sociability which he examined in his earlier research on the Faubourg Saint-Marcel ${ }^{88}$ While acknowledging the undoubted positive aspects of this participation in politics, he also notes its many excesses and dysfunctional dimensions. In particular, he highlights the effects of absenteeism, which resulted in the sections ceding their power to pressure groups, that is, to veritable citizen oligarchies whose members had made political action a profession. These radicalized minorities were masters of the techniques that allowed them to control the life of the sections, quite often with the aim of discouraging the participation of their opponents. Thus, practices tainted by maladministration were pushed beyond the limits of legality and legitimacy by a tendency to consider "Public Safety" as a sort of supreme law of the land. ${ }^{89}$ This led to a curious phenomenon: the same manipulative practices, and the same language of democracy and protest that had earlier fostered the creation of new forms of political sociability and the politicization of social protest and economic demands now, in contrast, drove democratic participation into an impasse.

It is in this context that, according to Burstin, the obsession with conspiracies arose. $^{90}$ In a climate of uncertainty and growing fear, the obsession first took shape within the popular imagination but then succeeded in contaminating and conditioning the Revolution's entire political class. Burstin is aware that conspiracy phobia was also a convenient expedient, and points out that the broadening of participation to layers of society previously precluded from direct access to politics led to a simplification of discourse and the dramatization of expression. If, as the Encyclopédie stated, the plot of a play served to plunge the spectator into uncertainty as to the fate of its characters, then the effect of brandishing the idea of conspiracy and presenting

88. Haim Burstin, Le faubourg Saint-Marcel à l'époque de la Révolution. Structure économique et composition sociale (Paris: Société d'études robespierristes, 1983).

89. Burstin clearly has Richard Cobb's interpretation in mind, though he critically 
a misleading appreciation of the relations between objective and subjective factors must have been to create uncertainty in public opinion. ${ }^{91}$ Militant patriotism could then contrast the secretive nature of conspiracy with the ideal of transparency, which in practice translated into the surveillance of suspicious behavior through the vigilance of the masses, and hence the glorification of the figure of the sentinel maintaining a meticulous, pervasive watchfulness against the enemy within. ${ }^{92}$

All these characteristics make up what Burstin calls "revolutionary protagonism" or, more precisely, "popular protagonism." He considers that the explanation of such a phenomenon lies not in the psychological register, as in Tackett's analysis, but in the powerful new mechanism of participation in public life made possible by the experience of direct democracy ${ }^{93}$ Through this experience, individuals were able to situate their own existence within a broad symbolic schema that gave meaning to their acts, and they were carried along by a sort of "epic inspiration" that left them feeling that their own destiny and that of the collectivity converged. ${ }^{94}$ Once under way, such popular activism was difficult to contain. It spread spontaneously, found its way into the folds of everyday life, escaped all control and seized upon new roles and functions. It was dominated by a handful of "enforcers," typified by Stanislas-Marie Maillard, known as Tape-Dur (the Hard-Hitter), a leading agitator during the journées of October 5 and $6,1789 .{ }^{95}$ However the fairly questionable, and sometimes aberrant, participation of such individuals is considered by Burstin to be one aspect of the revolutionary habitus: an extreme example-and one that is unquestionably harmful to the image of the Revolution - of a more general trend of thought characteristic of the revolutionary experience as a whole. As a result, the Maillard of 1789 is described in much the same terms as the Maillard of the years that followed, when he again played a leading role in the September massacres of 1792 .

Sparing no detail of the brutal gamut of revolutionary violence, Burstin parades before us figures such as Desnot (who beheaded Bernard-René Jourdan de Launay, the governor of the Bastille) or Nicolas, nicknamed Coupe-Tête (the Head-Hunter), who decapitated the corpses of the royal guards killed on the morning of October 6, 1789. He refuses to see such behavior as the expression of an atavistic barbarism and, noting the population's general consensus in favor of the most extreme forms of violence, explains these acts in terms of a sort of provisional stretching of the limits of legality that occurs in certain periods of collective overexcitement. In the face of traumatic events, according to Burstin, the revolutionary climate led to a raising of the threshold of what was acceptable, as actions

91. Ibid., 145. The Encyclopédie, ou Dictionnaire raisonné des sciences, des arts et des métiers was edited by Diderot and Jean le Rond d'Alembert, and published between 1751 and 1772. 92. Burstin, Révolutionnaires, 148. See Lynn Hunt's classic analysis in her Politics, Culture, and Class in the French Revolution (Berkeley: University of California Press, 1984).

93. Burstin, Révolutionnaires, 170.

94. Ibid., 176.

95. Alexandre Sorel, Stanislas Maillard, l'homme du 2 septembre 1792. Notice historique sur sa vie ... (Paris: Aubry, 1862). 
normally considered repugnant became tolerated. It was in this way that extremism, he claims, gradually and painlessly became integrated into everyday revolutionary practice. ${ }^{96}$

This brings Burstin to the core of the problem: the inability of the political authorities to lay to rest, once and for all, the troubling specter of popular mobilization. This uncontainable spontaneity survived for a considerable length of time, despite attempts to channel it into fetes or rituals and the implementation of measures (ranging from those of Isaac Le Chapelier to those of Robespierre) aimed at limiting active, sometimes armed, popular participation. This situation leads to another question: Why did repeated attempts at normalization fail, thus opening the door to instability? Burstin's answer is that this inability to put a stop to the Revolution was due to its creation of new identities, which endured like clothes that one is reluctant to part with. It was not easy to force people to return to their former occupations when the Revolution had changed them profoundly, shaping them into different people who were prepared to die rather than abandon their new identity. The phenomenon, therefore, was a consequence not of the politics of the time (even if, as Burstin admits, it was difficult to bring the Revolution to an end while continuing to call on the force of the people) but of a sort of existential resistance. ${ }^{97}$

This perspective, which roots the radicalization of vast popular layers of society in a largely autonomous subjectivism, eschews the need to situate it in the more general context of political struggle. Burstin's model of the triggering of popular political action, described at such length in the pages of his book, takes no account of the manipulative dimension of the rabble-rousers underlined by Taine, but it also refuses the existence of a system of political mediation in which agitation, raised to the level of insurrection, could be considered a weapon for broad political change. This creates an obvious obstacle to situating the Terror. Ultimately, it is explained through a series of disruptive events, above all military conflict and civil war, that together imposed a culture of emergency. By removing all social checks and balances, this culture made the unthinkable possible. All of which is another-astute-way of calling on what are traditionally referred to as "circumstances." Burstin's conclusion, then, is meant to be heartening but in fact provides scant reassurance: the principal ideological systems (like the great religious beliefs) have all claimed many victims. ${ }^{98}$

96. Ibid., 324

97. Ibid., 389.

98. Ibid., 417. Burstin borrows a sentence from Benjamin Fondane, Rimbaud. Le voyou et l'expérience poétique (Brussels: Complexe, 1979; repr. 1990), 168: "I term 'Idea' anything in the name of which white people are prepared to kill black people, Germans to kill Jews, the bourgeoisie to kill Communists, Communists to kill Trotskyites, Mexicans to kill Catholics, Catholics to kill Protestants, one man to kill another. I know of no Idea that has less than a hundred thousand deaths on its conscience." 


\section{The Structure of Revolutionary Politics}

Despite their considerable differences, the three books presented here have certain points in common. The first is that they all offer an interpretation of the French Revolution that echoes the interrogations of the present day. Each of the authors adopts a perspective that fits within current debate, updating the narrative of a Revolution that is called upon to provide answers to the new questions arising at the start of this twenty-first century. Burstin is prepared to distance himself from his object and openly states that he feels no nostalgia for the times of poisonous ideological conflicts. ${ }^{99}$ He seeks to reexamine the lived experience of the Revolution by immersing himself in a world that is "other," putting himself in the shoes of an inquisitive traveler or an "anthropologist." The key word here is the very current term "experience," a dimension that favors the interaction between individual and group, the creation of new feelings of belonging, and the transformation of identities. According to Israel, by contrast, the Revolution can be summed up in the principles set out in the Declaration of the Rights of Man, explicitly affirmed in the constitutions of 1791, 1793, and 1795 and applied in a series of laws that have changed the world. He thus offers us a view of the Revolution as the experimental field of a philosophical vision that is at once universalist, democratic, libertarian, and progressive. In sum, it was the first battle in a long and as yet indecisive war for the affirmation of human rights. Lastly, Tackett's account of what could be called "the emotional history of the Revolution" results from his quest for new ways to explain the appearance of its "dark star," ${ }^{100}$ the Terror. His research belongs to the relatively recent historiographical worksite known as the "history of emotions," an attempt by historians to establish links with insights from the neurosciences but also (and despite the relative lack of coherence between the two) with the importance attached to the emotional dimension conveyed by so-called "historical memory." 101

The three books have a second feature in common: they refuse to attribute responsibility for the obscure evils of the twentieth century to the French Revolution, that is, to consider it as the matrix of the transformation of revolutionary utopia into the despotic social engineering often defined as the crucible of totalitarianism. With Burstin, this rejection is explicit and total. Israel partially accepts the charge, but shifts the burden of blame onto the authoritarian, populist ideology of

99. See, however, the review by Claude Mazauric in Annales historiques de la Révolution française 377 (2014): 221-22.

100. The expression is borrowed from Antoine de Baecque, "Apprivoiser une histoire déchaînée. Dix ans de travaux historiques sur la Terreur (1992-2002)," Annales HSS 57, no. 4 (2002): 851-65, here p. 862.

101. On this point, see the introduction to Francesco Benigno, Parole nel tempo. Un lessico per pensare la storia (Rome: Viella, 2013). 
the Jacobins, which he considers to be a degenerate form of the true Revolution. ${ }^{102}$ Lastly, Tackett sets out to demonstrate that it is not-or not solely-political theory that influences individuals and causes them to take one course of action or another. It is precisely because these three projects resist the idea that the French Revolution laid the foundation for the horrors of totalitarianism that they offer a new interpretation of revolutionary violence and explore the question of the origins of the Terror. Although their positions differ, they tend to distance themselves both from the classic thesis that locates these origins exclusively in "circumstances," and from that-expressed in the work of Furet-which considers ideological escalation the root cause of the erupting violence that marked the first three years of the Republic.

Tackett addresses this task by adding the role of emotional involvement-in particular the fear engendered by belief in a counterrevolutionary plot-to the list of factors generally used to explain revolutionary violence. For his part, Israel sees the Terror as a deflection of the Revolution from its true course. This is not, however, a reference to the classic polarity between the liberal, constitutional revolution of 1789 and its democratic but violent counterpart of 1792. Rather, the opposition is between the republican Girondin revolution of 1792 (which in a sense incorporated the advances and conquests achieved since 1789) and the despotic revolution of 1793-1794. Lastly, Burstin underscores the extent to which the radical revolutionary experiment involved elements that had distorting, not to say antidemocratic, effects on political events. And yet, while recognizing that these effects led up to the Terror, he does not conclude that they were what caused it.

Finally, mention must be made of a less appealing aspect common to all three books: a sort of shared refusal to take into account the revolutionary political structure, a system which cannot be reduced to the ideological convictions, outpourings of emotion, and collective participatory experiments that were unquestionably features of it. After reading these works, it seems legitimate to speculate that the revolutionary experience also enabled the striking of innovative political balances that, though inherent to representative democracy, were problematic precisely because they had never been tried before.

From the moment that the Estates General proclaimed themselves the National Assembly, the structure of revolutionary politics gravitated around three poles: the Assembly, the court (replaced, after the fall of the monarchy, by the executive) and the "street," comprising the press as a whole, the sections of the Paris Commune, and various clubs. It was only through the pressure of the street that the Assembly attained, without discussion, its central position. At the same time, however, constant recourse to popular mobilization undermined its autonomy-a point which largely precludes comparison with the English parliamentary system. ${ }^{103}$

102. A totally different perspective can be found in Dan Edelstein, The Terror of Natural Right: Republicanism, the Cult of Nature, and the French Revolution (Chicago: University of Chicago Press, 2009).

103. On the relation between popular sovereignty and representation, see in particular Pierre Rosanvallon, Le peuple introuvable. Histoire de la représentation démocratique en France (Paris: Gallimard, 1998), and his La démocratie inachevée. Histoire de la souveraineté du peuple 
The pivotal political moments of the Revolution were marked by the active role of the street, bolstered by the widespread ideology of popular sovereignty and the superior will, over which the elected legislators did not have a monopoly. The new source of sovereignty, the people, presented itself as both an abstract actor and a concrete player (in the form of the sans-culotte, an identitarian construct created as a parallel to its antithesis, the aristocrat), embodied in radicalized minorities exercising constant pressure on the Assembly. As a result, there was a tendency for popular pressure to be used in various ways to influence political decision-making: with petitions, through the presence of rowdy spectators in the Assembly (the famous "tyranny of the galleries"), and by means of demonstrations. ${ }^{104}$ This meant that minority groups in the Assembly were able to call upon outside pressures capable of overturning parliamentary balances. Fierce competition for control of the street developed between the various political factions, both within and outside the Assembly_the winner was whoever managed to obtain a consensus of the most active and the most politicized social strata. This in turn triggered an escalating game of demagogic one-upmanship which the historiography has often analyzed solely from the standpoint of a progressive ideological escalation, but which actually had a political dimension that should not be overlooked. The crucial summer months of 1792 amply illustrate this phenomenon: in an explicit motion approved on August 8 by a vote of 406 for and 206 against, the majority of the Assembly favorable to the constitutional monarchist party refused to suspend the sovereign and pledged its continued support for Lafayette, who had called for the exemplary punishment of the instigators of the June 20 demonstration. The answer of the street, organized by the parliamentary minority, came in the form of the journée of August 10. The following spring, the same scenario was played out in the Convention. In March, while the Hébertists were setting fire to pro-Girondin printing shops, the street vainly called on the Convention to expel the Brissotins. On May 31, the Convention found itself besieged and threatened by an alliance between thirty sections (which appointed a central committee), the Commune, and various radical minority groups in the Assembly. Here again, the majority resisted to the best of its ability, until its June 2 capitulation in the face of an ultimatum from the armed National Guard commanded by François Hanriot.

Ideological extremism was not, then, merely an inevitable consequence of intrinsically illiberal theoretical premises, but was also linked to a political structure in which hegemony over the sections was a necessity, since it was possible to intervene in the decision-making process and determine its outcome through an "appeal to the people." This led to a constant tendency to go beyond the limits of legality,

en France (Paris: Gallimard, 2000). See also Marcel Gauchet, La Révolution moderne, vol. 1, L'avènement de la démocratie (Paris: Gallimard, 2007).

104. This is a frequent theme in the memoirs of those involved in the Convention. See Sergio Luzzatto, Il Terrore ricordato. Memoria e tradizione dell'esperienza rivoluzionaria (1989; repr. Turin: Einaudi, 2000), 41. This work has been translated into French: Luzzatto, Mémoire de la Terreur. Vieux montagnards et jeunes républicains au XIXe siècle, trans. Simone Carpentari-Messina (Lyon: Presses universitaires de Lyon, 1991). 
and ultimately made it impossible to stabilize the regime. From this standpoint, populism was not solely an essential rhetorical theme; it was also the solicitation of a sort of external political support, culminating at times in the extreme gesture of insurrection.

In all three books considered here, this singular structuration of politics remains in the shadows. It might, however, offer a different answer to the questions which they raise. The theme of violence in particular, so central for today's sensibilities, ${ }^{105}$ could usefully be reappraised from this perspective. The exercise of violence by the masses can be seen not simply as the outcome of fear, of populist ideology, or of militant activity, but also as an effect of incitations to action originating, since the dawn of the Revolution, among different groups of the patriotic ruling class. Initially employing forms of instigation reminiscent of ancien régime pressure groups-ranging from tacit approval to paid incitementthese solicitations underwent a considerable transformation with the gradual broadening of political participation. ${ }^{106}$ Through the mediation of various clubs, political and personal links were progressively established between a number of popular sections, elements of the National Guard, and certain already existing groups, first in the Constituent Assembly, then the Legislative Assembly, and lastly in the Convention.

This should not be seen simply as manipulation by shadowy individuals pulling the strings of a movement carried forward by others, but as the schooling in politics of workers and artisans from the lower-class neighborhoods of Paris, including the Faubourg Saint-Antoine, so prominent in many of the revolutionary journées. By dint of indoctrination and incitement to rise up, the ancien-régime crowd learned (and helped define) the new forms of politics, metamorphosing into the revolutionary crowd-a political subject that was far more difficult to manage, as many a "sorcerer's apprentice" of 1789 was to discover in due course. This was a complex process that also profoundly affected the world of women, a process in which taking the floor to speak and taking up arms went hand in hand. ${ }^{107}$ The sansculotte movement was the most obvious consequence of this acclimatization of the masses to the Revolution, a culture shift that did not prevent repeated attempts to manipulate and control the actions of the street, but which rendered it all the more difficult to manage, with increasingly unpredictable results.

From this viewpoint, it is important for future research to map more clearly the links between the sometimes shifting, but most often fairly continuous,

105. Michel Biard and Hervé Leuwers, eds., Visages de la Terreur. L'exception politique de l'an II (Paris: Armand Colin, 2014), 157; Jean-Clément Martin, Violence et révolution. Essai sur la naissance d'un mythe national (Paris: Seuil, 2006).

106. See, however, the viewpoint set out in Peter R. Campbell, "Perceptions of Conspiracy on the Eve of the French Revolution," in Conspiracy in the French Revolution, ed. Peter R. Campbell, Thomas E. Kaiser, and Marisa Linton (Manchester: Manchester University Press, 2007), 15-41.

107. Jean-Clément Martin, La révolte brisée. Femmes dans la Révolution française et l'Empire (Paris: Armand Colin, 2008). 
political orientations of the Paris sections and the groups vying with each other for power in the Assembly. ${ }^{108}$ A chart of this type would make it possible to situate more accurately the political activity of crucial figures-such as Maillard, Antoine Santerre, ${ }^{109}$ Pierre-Augustin Hulin, Claude Fournier (nicknamed "the American" ${ }^{110}$ ), and Hanriot - who were able to control, steer, and direct armed popular mobilization.

As in any revolutionary period, the spread of firearms among large sections of the population enhanced the role of those who were in a position to use them if need be. Each political faction thus managed to have at its disposal not merely its own press organs and its power base among the sections, but also its own gangs of enforcers, armed activists capable of influencing the ranks of the populace and providing the backbone of demonstrations and insurrections. The journée of June 20,1792, already evoked above, was preceded by demonstrations organized by pro-Girondin sections demanding the recall of the dismissed ministers, and was prepared during a meeting of various groups at the home of Santerre, the National Guard leader of the Faubourg Saint-Antoine district. ${ }^{11}$ In turn, the purge of the Brissotins the following year was organized by four different factions: Hébertists, the "Enragés" led by Jacques Roux, Robespierrist Jacobins, and Dantonists. ${ }^{112}$ It is thus significant that in the bloody conflict which ensued, the groups that had been defeated in the factional struggles and found themselves declared outlaws sought to react in kind, through an "appeal to the people" for a mass insurrection aimed at reversing the situation. But the attempt served little purpose: both Hébert and Robespierre were immediately arrested and executed. ${ }^{113}$

From Le Chapelier to Jean-Marie Roland, from Danton to Robespierre, the revolutionary leaders charged with maintaining public order made repeated but vain attempts to sever the link between political struggles in the Assembly and the mobilization of armed crowds, as if this were the only way to stabilize political life and thus bring the Revolution to its conclusion. ${ }^{114}$ From this perspective, the harsh repression that followed the Montagnard insurrection of 1 Prairial Year III (May 20, 1795) —with thousands of arrests and mass executions,

108. Besides Monnier, L'espace public démocratique, see the exemplary case analyzed in Haim Burstin, Une révolution à l'œuvre. Le faubourg Saint-Marcel, 1789-1794 (Seyssel: Champ Vallon, 2005).

109. Antoine-Étienne Carro, Santerre. Général de la République française: sa vie politique et privée écrite d'après des documents originaux laissés par lui, et les notes d'Augustin Santerre, son fils ainé (Paris: Ledoyen, 1847).

110. Yves Blavier, Fournier l'Américain. Mémoires secrets et autres textes (Paris: L'Harmattan, 2010).

111. Tackett, The Coming of the Terror, 176.

112. Israel, Revolutionary Ideas, 459.

113. Colin Jones, "The Overthrow of Maximilien Robespierre and the 'Indifference' of the People," American Historical Review 119, no. 3 (2014): 689-713.

114. Howard G. Brown, Ending the French Revolution: Violence, Justice, and Repression from the Terror to Napoleon (Charlottesville: University of Virginia Press, 2006). 
including the six "Jacobin" deputies known as the "Martyrs of Prairial"115 represented a turning point in the sense that it made it much harder to "appeal to the people." 116

Given that popular violence acquired a different meaning once it became part of the structure of revolutionary politics, even the slogan "Put Terror on the agenda" can be seen as an attempt to decapitate, and thus disarm, hostile factions (over and above its function as propaganda calling for the annihilation of counterrevolutionaries). While it appeared to run counter to popular anger, this slogan expressed the need for control over the potential for subversion that threatened political representation both from the outside and from within, a control that was to see its full implementation during the Directory period. Indeed, a robust continuity can be observed between Robespierre's policy aimed at eliminating the "opposing extremisms" of the Exaggerators and the Indulgents, and the pendulum swings of the Directory's tendency to strike alternately at the royalist right and the radical left. In a certain sense, the Directory's repeated demonstrations of force were a continuation of the journées. ${ }^{117}$

This perspective naturally obliges us to rethink Bronisław Baczko's distinction between a journée and a coup d'état, between movements "from below" and those "from above" - the former having armed crowds as their protagonists and the latter orchestrated by the armed forces. ${ }^{118}$ The three books examined here neglect this point, but it is worth invoking since an "appeal to the people" and an "appeal to the army" are in many ways closely linked. In some cases, as Baczko himself recognizes, the distinction between the two is not easy to draw. The siege of the Convention on May 31, 1793, by Hanriot's National Guard represents a sort of minority coup de force against the majority of the Assembly. In this instance, the "people" were represented by the uniforms and bayonets of the "patriots." One can nevertheless go further and note that the participation of National Guardsmen and volunteers from the provinces was particularly significant in the weeks leading up

115. Françoise Brunel and Sylvain Goujon, Les martyrs de Prairial. Textes et documents inédits (Geneva: Georg, 1992); John Renwick, "Les 'martyrs de Prairial': légende bleue, légende blanche, légende rouge," in "Gilbert Romme," special issue, Annales historiques de la Révolution française 304, no. 1 (1996): 417-29. See also the following chapters in the same volume: Haim Burstin, "Échos faubouriens des journées de Prairial," 373-85; Antoinette Ehrard, "La mémoire des 'Martyrs de Prairial' dans l'espace public," 431-46; Sergio Luzzatto, "Le rêve d'un 'lit de justice' populaire au printemps de l'an III," 361-72; Raymonde Monnier, "L'étendue d'un désastre: Prairial et la révolution populaire," 387-400.

116. Evgenii V. Tarlé, Germinal et Prairial, trans. Jean Champenois (Moscow: Foreign Languages Publishing House, 1959); Kåre D. Tønnesson, La défaite des sans-culottes. Mouvement populaire et réaction bourgeoise en l'an III (Oslo/Paris: Presses universitaires/R. Clavreuil, 1959); Richard Cobb and George Rudé, "The Last Popular Movement of the Revolution in Paris: The 'Journées' of Germinal and Prairial of Year III," in Kaplow, New Perspectives on the French Revolution, 254-76.

117. Scuccimarra, La sciabola di Sieyès, 101. 
to August 10,1792, as well as those that followed-that is, during the period identified by Lefebvre in his famous 1942 lecture as the "first Terror." 119 The role of the National Guard, which was both popular and military, was to prove decisive: this was the corps that Lafayette called upon, in the aftermath of the journée of June 20, 1792 , as he sought to impose order by force, using his ascendancy as its former commandant-general. However, he underestimated-to his cost-the process of radicalization that was already under way: the National Guard no longer answered to a sole source of command and was less disposed than ever to defend a king who had ceased to enjoy popular legitimacy. ${ }^{120}$ But later, after Thermidor, the concepts of an "appeal to the people" and an "appeal to the army" became superimposed and merged into one. Quite frequently, the interventions of the street and the army occurred simultaneously: such was the case with the Montagnard insurrection of 1 Prairial Year III (May 20, 1795), which saw the Convention "taken hostage" and then released during the night thanks to the joint intervention of certain moderate sections and the military. ${ }^{121}$ Similarly, on 4 Prairial of the following year, an invasion of the Faubourg Saint-Antoine was launched at the initiative of armed groups from the pro-government sections, with the aim of arresting the murderer of Deputy Féraud: the Convention eventually resolved to order the district to hand over the muderer and the weapons, or find itself besieged, deprived of food, and declared to be in a state of rebellion. On yet another occasion, the Convention initially resisted the insurrection of 13 Vendémiaire Year IV (October 5, 1795) by returning the weapons previously confiscated from the "Jacobins" and "terrorists," before finally calling in the army.

Even during the Directory period, the political structure was plagued by persistent deviations from legality. In this case, the object was to influence, or even overturn, the political balances resulting from the elections of political representatives. ${ }^{122}$ The difference, however, was that the threat or actual use of violence by the bloc of Directors was perpetrated not by an armed crowd, but by the army. The cannonballs and "whiff of grapeshot" fired at the crowd gathered on the steps of the church of Saint-Roch on 13 Vendémiaire Year IV (October 5, 1795) thus inaugurated a new period, in which the heirs of Thermidor manipulated or often infringed the principles of the constitutional order then in force and guaranteed by the Constitution of Year III. The outcome was the coup of 18 Brumaire (November 9, 1799). In reality, what Baczko calls the contradiction of "the democratic space established by revolution" 123 continued with the revolutionary implementation of the

119. Georges Lefebvre, La Révolution française. La première Terreur (Paris: Tournier et Constans, 1946).

120. Tackett, The Coming of the Terror, 179-80.

121. Bronisław Baczko, Ending the Terror: The French Revolution after Robespierre, trans. Michel Petheram (Cambridge: Éd. MsH/Cambridge University Press, 1994).

122. On continuity in the purges of the legislative body from Thermidor onward, see Mette Harder, "A Second Terror: The Purges of French Revolutionary Legislators after Thermidor," French Historical Studies 38, no. 1 (2015): 33-60.

123. Baczko, "Institutions démocratiques," 58. 
opposite of democracy - the authoritarian dictatorship and subsequent imperial monarchy established by the officer who had ordered the cannonade, General Napoleon Bonaparte.

Francesco Benigno

Universitá degli Studi di Teramo 